\title{
EFEKTIVITAS CARA PEMASAKAN TERHADAP KARAKTERISTIK FISIK MASAKAN DAGING BABI HUTAN
}

John E. G. Rompis dan Sylvia Komansilan

\author{
Fakultas Peternakan Universitas Sam Ratulangi Manado 95115 \\ jegronne@yahoo.co.id
}

\begin{abstract}
ABSTRAK
Tujuan penelitian ini adalah untuk mengetahui karakteristik fisik masakan daging babi hutan yang dimasak dengan cara pemasakan berbeda. Penelitian dilakukan dengan menggunakan Rancangan Acak Lengkap (RAL) melalui tiga perlakuan wadah (amboo, wajan dan "belanga tanah") dengan bumbu berupa cabai rawit, daun bawang, kemangi, sereh, jahe dan daun jeruk suangi. Untuk karakteristik fisik $(\mathrm{pH}$, kadar air, dan Daya Mengikat Air) dianalisa di laboratorium Teknologi Hasil Ternak. Analisis data menggunakan ANOVA dan bagi perlakuan yang berbeda nyata dilanjutkan dengan uji wilayah berganda Duncan. Hasil penelitian menunjukkan bahwa perbedaan wadah pemasakan mempengaruhi karakteristik fisik. Dari penelitian ini disimpulkan bahwa dilihat dari $\mathrm{pH}$, kadar air dan daya mengikat air maka pemasakan menggunakan wadah bamboo memberikan hasil terbaik.
\end{abstract}

Kata Kunci: Wadah pemasakan,

Karakteristik fisik, Daging babi hutan.

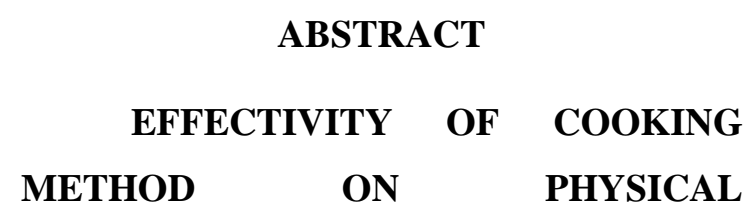

\section{CHARACTERISTIC OF COOKERY} WILD PIG MEAT. The objective of this study was to evaluate the physical characteristic of cookery wild pig meat with different cooking methods. Research was done using completely randomized design with three treatments of coocing method (bamboo cooker apparatus, stainless cooker apparatus and soil cooker apparatus) and five replications in each treatment. All treatments were added with spicy ingredients of cabai, daun bawang, kamangi, sereh, jahe, and daun jeruk. Physical characteristics were including $\mathrm{pH}$, water content and water holding capacity, analized at animal product technological laboratory. Data were analyzed by analysis of variance model with Duncan statistical test for significant $\mathrm{F}$ test. Result study showed that different cooker apparatus affected significantly physical characteristics of cookery wild pig meat in term of $\mathrm{pH}$, water content and water holding capacity. It can be concluded that cooking method using bamboo cooker apparatus yield thye best physical characteristics of cookery wild pig meat.

Kata Kunci: Cooker apparatus, physical characteristic, cookery wild pig meat. 


\section{PENDAHULUAN}

Seiring dengan perkembangkan pembangunan nasional, maka pembangunan iptek di bidang teknologi hasil ternak perlu dikembangkan.Salah satunya adalah mengangkat potensi masakan tradisional daerah Minahasa yang pada gilirannya mampu menunjang ketahanan pangan.Masyarakat Minahasa sebagian besar gemar mengkonsumsi masakan tradisional daging babi hutan.Masakan daging babi hutan merupakan salah satu masakan khas Minahasa yang perlu dikembangkan sebagai salah satu komoditas andalan daerah, sekaligus merupakan salah satu cara diversifikasi pangan asal hewan. Sebagai hewan liar, babi hutan berpotensi untuk dimanfaatkan sebagai sumber daging konsumsi karena rasanya yang khas, enak, empuk dan bersari minyak. Selain itu hewan ini dianggap sebagai hama di beberapa tempat dan tidak dapat dikonsumsi oleh sebagian orang. Masyarakat Minahasa gemar mengkonsumsi masakan daging babi hutan karena secara umum memiliki perlemakan yang sedikit dibandingkan dengan daging babi domestik.Salah satu ukuran yang digunakan untuk menilai produksi ternak/hewan potong lainnya adalah persentase karkas.

Daging babi hutan yang dibuat masakan menggunakan beberapa bumbu dapur tradisional (rempah).Bumbu dapur tradisional adalah campuran rempah-rempah yang digunakan sebagai penyedap.Pemberian bumbu/rempah pada masakan tradisional selain dimaksudkan untuk membangkitkan selera makan dan memberikan citara yang khas pada suatu masakan, ternyata memiliki manfaat yang belum banyak diketahui orang. Pemasakan merupakan proses pengolahan dengan panas yang paling sederhana dan mudah dilakukan. Tujuan pemasakan terutama untuk memperoleh masakan yang lezat dan enak, selain itu untuk memperpanjang daya simpan. Pada pemasakan daging babi hutan, sebelum dicampurkan bumbu diolah terlebih dahulu. Selain bentuk bumbu, cara masak tradisional masyarakat Minahasapun berbeda-beda. Ada yang memasak menggunakan wadah bambu atau wajan dengan sumber panas berasal dari kayu bakar.Keragaman cara pengolahan masakan daging babi hutan di daerah Minahasa memungkinkan terjadinya perbedaan karakteristik fisik. Oleh karena itu telah dilakukan penelitian dalam bentuk kajian terhadap karakteristik tersebut.

Sebagai hewan liar, babi hutan berpotensi untuk dimanfaatkan sebagai sumber daging konsumsi karena rasanya yang khas, enak, empuk dan bersari minyak.Masyarakat Minahasa lebih menyukai daging babi hutan karena secara umum memiliki perlemakan yang lebih sedikit dibandingkan dengan babi domestik.Hewan liar baik yang yang sudah dijinakkan maupun yang belum, selalu diburu guna mendapatkan daging untuk kebutuhan konsumsi manusia.Salah satu jenis hewan liar yang banyak diburu di bagian utara pulau Sulawesi adalah babi hutan (Sus celebensis).Hewan ini diburu karena dagingnya yang khas, enak, empuk dan bersari 
minyak.Salah satu ukuran yang digunakan lainnya adalah persentase karkas.Persentase karkas babi hutan sebesar $65.28 \%$. Selain itu pula hasil penelitian Reksowardojo (1995) memberikan informasi kandungan nutrisi daging babi hutan segar sebagai berikut: $70.98 \%$ air, $20.79 \%$ protein, $0.89 \%$ lemak, $20.24 \%$ ca dan $0.21 \% \mathrm{P}$.

Pemasakan daging babi hutan biasanya menggunakan beberapa bumbu dapur tradisional (rempah).Bumbu tersebut berupa cabai rawit, daun bawang, kemangi, sereh, jahe dan daun jeruk suangi.Pemberian bumbu/rempah pada masakan tradisional selain dimaksudkan untuk membangkitkan selera makan dan memberikan citara yang khas pada suatu masakan, ternyata memiliki manfaat yang belum banyak diketahui orang.Bumbu/rempah berfungsi juga sebagai antioksidan (Mulyani et al., 1998), bahan pengawet alami dan dapat mencegah beberapa jenis penyakit diantaranya hiperkolesterolemia. Menurut Walangitan et al. (2000), rempah-rempah digunakan sebagai bumbu masakan antara lain untuk memberi rasa istimewa pada makanan, menutupi/menghindari aroma bahan asal, menutupi kerusakan makanan akibat pemasakan dan untuk meningkatkan pengolahan makanan yang bermutu rendah. Oleh karena itu bagi orang Minahasa, bumbu/rempah sangat berperan penting dalam menentukan citarasa suatu masakan yang disukai serta aman untuk dikonsumsi oleh masyarakat. Komponen utama dalam rempahrempah yang berperan adalah minyak atsiri untuk menilai produksi ternak/hewan potong (yang menyebabkan aroma yang khas), dan resin yang terdapat dalam bentuk oleoresin. Minyak atsiri dan oleoresin yang terkandung pada bahan berperan memberi rasa dengan karakteristik dan individualitas bumbu utama pada bahan.

Pada pemasakan daging babi hutan, sebelum dicampurkan bumbu diolah terlebih dahulu.Pengolahan dapat dilakukan dengan cara dihaluskan/digiling menggunakan blender dan bentuk kasar, yaitu dengan cara diiris-iris menjadi potongan rempah yang lebih kecil ukurannya. Beberapa metode yang dapat digunakan dalam pemasakan suatu bahan makanan antara lain pemanggangan, perebusan, pengukusan dan penggorengan.Dalam memasak suatu bahan pangan mentah menjadi suatu masakan pada umumnya menggunakan beberapa wadah pemasakan misalnya wajan, panci ataupun kukusan.Selain bentuk bumbu, cara masak tradisional masyarakat Minahasapun berbedabeda.Ada yang memasak menggunakan wadah bambu atau wajan dengan sumber panas berasal dari kayu bakar. Adapun penggunaan kayu bakar dimaksudkan untuk memberi rasa asap (smoky flavor) pada masakan.

Hasil penelitian ini diharapkan dapat memberi informasi mengenai karakteristik fisik masakan tradisional daging babi hutan ditinjau dari wadah pemasakan yang berbeda, serta membuka wawasan bagi perkembangan makanan tradisional Minahasa dalam hubungannya dengan pengetahuan di bidang teknologi hasil ternak ataupun teknologi 
pengolahan bahan pangan asal hewan. Selain itu pula tersedianya data sekaligus informasi tradisional Minahasa yang dapat menjadi komoditas andalan dan kebanggaan daerah, sekaligus meningkatkan daya konsumsi hasil penelitian bagi masyarakat Indonesia yang pada gilirannya mampu menunjang ketahanan pangan di daerah.

\section{MATERI DAN METODE PENELITIAN}

Penelitian ini dirancang sedemikian rupa untuk mendapatkan hasil yang sesuai dengan yang diharapkan.Tujuan penelitian ini adalah untuk mendapatkan informasi mengenaipengaruh wadah pemasakan yang digunakan oleh masyarakat Minahasa dalam mengolah masakan daging babi hutan terhadap karakteristik fisiknya.Penelitian ini dilakukan untuk menguji karakteristik fisikmeliputi $\mathrm{pH}$, kadar air, dan daya mengikat air. Pengujiandilakukan di laboratorium Teknologi Hasil Ternak, Fakultas Peternakan Unsrat Manado.

\section{Bahan}

Bahan baku yang digunakan dalam penelitian ini yaitu daging segar babi hutan bagian paha (ham) dari babi hutan yang berumur kira-kira 12 bulan.Daging segar babi yang dapat dipertanggungjawabkan secara ilmiah mengenai pengolahan makanan hutan digunakan sebanyak $15 \mathrm{~kg}$ dan dibeli dari salah satu pasar tradisional di Minahasa. Bumbu-bumbu yang digunakan seperti terlihat pada Tabel 1. Terdapat tiga wadah pemasakan yaitu menggunakan bambu, panci/wajan, dan "belanga tanah".

\section{Metode Penelitian}

Penelitian tahap kedua ini
dilaksanakan dengan
menggunakan
Rancangan Acak Lengkap (RAL) dengan 3
perlakuan berulangan 5 sesuaipetunjuk Steel
and Torrie (1995). Model rancangan
percobaannya adalah sebagai berikut:

$$
\mathbf{Y}_{\mathrm{ij}}=\boldsymbol{\mu}+\mathbf{I}_{\mathrm{i}}+\sum_{\mathrm{ij}}
$$

dimana :

$$
\begin{aligned}
& \mathbf{Y}_{\mathrm{ij}}=\text { nilai pengamatan } \\
& \boldsymbol{\mu}=\text { rataan umum } \\
& \mathbf{I}_{\mathbf{i}}=\text { pengaruh perlakuan ke-i } \\
& \sum_{\mathrm{ij}}=\text { pengaruh komponen galat }
\end{aligned}
$$

Parameter yang diukur dalam penelitian ini adalah karakteristik fisik yang terdiri dari:

1. $\mathrm{pH}$ (derajat keasaman)

2. Analisis Kadar air (AOAC, 1984).

3. Daya Mengikat Air (DMA) (water holding capasity)

Tabel 1. Komposisi Bumbu yang Diberikan pada Pemasakan Daging Babi Hutan.

\begin{tabular}{lc}
\hline Jenis Bumbu & Banyaknya (/kg daging) \\
\hline Cabai rawit (Caapsicum frustencen $\mathrm{L})$ & $200 \mathrm{~g}$ \\
\hline Daun bawang (Allium fistulosum $\mathrm{L})$. & 10 lembar \\
\hline Kemangi (Ocimum basilicum L.) & $1 \mathrm{ikat}$ \\
\hline Sereh (Cymbopogon citratus STAPF) & 5 batang \\
\hline Jahe (Zingiber officipale rose) & 1 potong \\
\hline Jeruk suangi (Citrus hyatrix) & 10 lembar \\
\hline
\end{tabular}




\section{HASIL DAN PEMBAHASAN}

Pengaruh Wadah Pemasakan terhadap Karakteristik Fisik Daging Babi Hutan

Pengaruh wadah pemasakan terhadap karakteristik fisik daging babi hutan disajikan dalam Tabel 2.

\section{Pengaruh Wadah Pemasakan terhadap pH Daging Babi Hutan}

Dari Tabel 2. terlihat bahwa $\mathrm{pH}$ masakan daging babi hutan berada pada kisaran 6.30 sampai 6.06. dimana yang menggunakan wadah bambu ternyata pHnya 6.3 diikuti oleh wadah wajan 6.2 , dan wadah belanga tanah 6.06. $\mathrm{pH}$ dari masakan daging babi hutan ini berada pada kisaran yang normal untuk daging babi yaitu $\mathrm{pH}$ terrendah 5.3 sedangkan $\mathrm{pH}$ tertinggi 6.9 untuk batas akhir yang didapat setelah reaksi perubahan glikogen menjadi asam laktat berhenti.

Hasil analisa sidik ragam (Anova) ternyata perlakuan yang menggunakan wadah bambu,wajan dan belanga tanah memberikan perbedaan yang nyata $(\mathrm{P}<0.01)$ terhadap perlakuan yang menggunakan wadah bambu wajan terhadap wadah $\mathrm{pH}$ masakan daging babi hutan.
Analisa lebih lanjut dengan menggunakan uji Duncan menunjukkan bahwa perlakuan yang menggunakan wadah bambu dan wajan memberikan perbedaan nyata $(\mathrm{P}<0.01) \quad$ terhadap perlakuan yang menggunakan belanga tanah.

\section{Pengaruh Wadah Pemasakan terhadap Kadar Air Daging Babi Hutan}

Dari Tabel 2. terlihat bahwa rataan kadar air masakan daging babi hutan berada pada kisaran $54.23 \%$ sampai $56.36 \%$. Dari hasil penelitian ini ternyata perlakuan yang menggunakan wadah belanga tanah yang paling rendah $54.23 \%$, diikuti oleh perlakuan wajan $56.36 \%$ dan yang tertinggi perlakuan bambu $66.15 \%$. Hasil penelitian ini masih berada dibawah kadar air daging segarbabi hutan yaitu 68-70\% ( Tobing, 2012).

Hasil analisa sidik ragam (Anova) menunjukkan bahwa perlakuan yang menggunakan wadah pemasakan berbeda (bambu, wajan, belanga tanah) memberikan hasil yang berbeda nyata $(\mathrm{P}<0.01)$ terhadap kadar air masakan daging babi hutan.

Tabel 2. Karakteristik Fisik Daging Babi Hutan yang dimasak dengan Wadah Pemasakan yang Berbeda.

\begin{tabular}{lccc}
\hline Karakteristik & Bambu & Wajan & Belanga Tanah \\
\hline $\mathrm{pH}$ & $6.30^{\mathrm{a}}$ & $6.20^{\mathrm{a}}$ & $6.06^{\mathrm{b}}$ \\
\hline Kadar Air & $66.15^{\mathrm{a}}$ & $56.32^{\mathrm{b}}$ & $54.23^{\mathrm{c}}$ \\
\hline DMA & $39.69^{\mathrm{a}}$ & $22.77^{\mathrm{b}}$ & $35.80^{\mathrm{c}}$ \\
\hline
\end{tabular}

Keterangan: superskrip berbeda pada baris yang sama menunjukkan perbedaan yang nyata $(\mathrm{P}<0.01)$ 
Analisa lebih lanjut dengan menggunakan uji Duncan memperlihatkan bahwa perlakuan yang menggunakan wadah bambu berbeda nyata terhadap wadah wajan dan wadah belanga tanah. Demikian juga perlakuan yang menggunakan wadah wajan memberikan perbedaan yang nyata terhadap perlakuan belanga tanah.

\section{Pengaruh Wadah Pemasakan terhadap Daya Mengikat Air Masakan Daging Babi Hutan}

Dari Tabel 2. terlihat bahwa rataan daya mengikat air oleh protein pada masakan daging babi hutan berada pada kisaran $22.77 \%$ - 35.80\%. Untuk daya mengikat air yang terendah berada pada perlakuan yang menggunakan wadah wajan $22.77 \%$, kemudian diikuti oleh perlakuan bambu, belanga tanah $35.80 \%$ dan belanga tanah.

Hasil analisa sidik ragam (Anova) memperlihatkan bahwa perlakuan yang menggunakan wadah pemasakan memberikan pengaruh yang berbeda $(\mathrm{P}<0.01)$ terhadap masakan daging babi hutan.Hasil analisa lebih lanjut dengan menggunakan uji Duncan memperlihatkan bahwa perlakuan yang menggunakan wajan berbeda nyata dengan perlakuan yang menggunakan belanga tanah dan bambu, perlakuan yang menggunakan belanga tanah berbeda nyata dengan bambu. Ini berarti perlakuan yang menggunakan wadah bambu kemampuan untuk mengikat airnya lebih baik diikuti oleh wadah belanga tanah dan wajan yang paling sedikit kemampuannya untuk mengikat air.

\section{KESIMPULAN}

Dilihat dari $\mathrm{pH}$, kadar air dan daya mengikat air maka pemasakan menggunakan wadah bambu memberikan hasil terbaik.

\section{DAFTAR PUSTAKA}

AOAC. 1984. Official Method of Analysis. Assosiation of Official Analytical Chemist. Washington, DC.

Mulyani, I., N.L.P. Nienaber, and S. Fardiaz. 1998. Kajian aktivitas antioksidan berbagai bumbu tradisional olahan industri. J. Ilmu dan Teknologi Pangan Vol. 3. No. 1:1-12.

Reksowardojo, D.H. 1995. Studi kemampuan reproduksi dan produksi babi rusa (Babyrousa babyrussa celebensis Deniger) melalui upaya budidaya. Disertasi. Program Pascasarjana IPB. Bogor.

Steel, R.G.D., and J.H. Torrie. 1995. Prinsip dan Prosedur Statistik, suatu pendekatan biometrik. Alih Bahasa B. Sumantri. PT. Gramedia Pustaka Utama. Jakarta.

Tobing, S.W.L. 2012. Perbandingan kualitas karkas dan daging antara babi peliharaan dengan babi hutan. Artikel. Program Pascasarjana Universitas Andalas Padang.

Walangitan, A.J.V., M.S.Y. Lumingkewas, N.P. Kumolontang, A.M. Salmon, A. Mamesah, and M. Yetty. 2000. Pembuatan bumbu inti masakan Minahasa. Laporan penelitian Balai Perindustrian. Manado. 